with distinct tissue changes. Now there is a mass of evidence of an unexceptionable kind which shows that the influence exerted by blistering in neuralgia is by no means always or usually depressing to nerve functions. On the contrary, where the influence is so applied as to exert a moderate effect upon the stimulated nerve, there can be little doubt that its tendency is to restore functions in the nerve itself, in the nerve-centre, and in other nerves which are centrally connected with it. I can see, therefore, no theoretic objections to the belief that stimulation of the ends of peripheral nerves may sometimes produce reflex effects of a beneficial kind even in inflammatory affections. Only, and this I insist upon, to attempt to secure these benefits without the most precise attention to the physiological relations of the nerves of the irritated part with those of the organ we seek to influence is entirely absurd. For example, there is an affection of which, though it is rare, most persons have seen one or two cases, in which blistering is one of the stock remedies-I mean the severe facial neuralgia which occurs in persons over the middle age. This neuralgia is often attended with secondary inflammations of tissues to which the branches of the painful nerve are distributed. If in this condition counter-irritation be applied either directly to the painful nerve, or, on the other hand, at any indifferent part, the effect is either nil or else impairs still further the nerve's functions. But if a blister be applied over the branches of the cervico-occipital nerve at the nape of the neck, a reflex stimulation is produced, the effects of which are often very beneficial, not merely to the pain, but also to the secondary affections ; for instance, the spasmodic twitchings cease, the tender and tumid points become less swollen and painful, and the exaggerated secretions from the eye and nostril are reduced. I cannot but suppose that in cases where blisters have seemed really to exercise a powerful influence on inflammations of distant organs, it must have been because a lucky chance applied the irritation to a nerve centrally connected with the nerves of the affected part.

A third class of organs which Dr. Dickinson enumerates, by means of which a real influence doubtless may be exerted on distant organs by an irritated skin surface is the absorbents. And here, as he justly remarks, the action would be altogethex bad. The only effect which the absorbents would assist in carrying out is the possible transmission into the system of morbid matters from the wound which we have gratuitously made. I need hardly tell you, in view of the recent experiments on inoculation, that this is no imaginary danger, but, on the contrary, might prove very serious to persons of a certain constitution.

One other method in which a blister can act remains to be discussed ; but it is one to which the term counter-irritation is singularly inapplicable. I refer to the direct transmission of the irritant action from the surface irritated to tissues immediately or a very short distance beneath it. Such an action as this is commonly altogether mischievous. For instance, I entertain no doubt whatever that I have seen a mild inflammation of the pericardium or pleura converted into a severe one by too zealous blistering at a critical moment in the early stage. It is highly probable that the same kind of effect is produced on the vessels of the affected part as that which can be seen to occur when we drop mustard or croton oil on the delicate web of a frog's foot-viz., a perfectly paralytic dilatation of the small arteries. A very different effect, however, may, I believe, be produced by the use of the milder irritants (one should rather call them stimulants) just sufficiently near to the inflamed part to exercise a very mild influence upon its bloodvessels. There can be little doubt that here, instead of increasing the tendency to dilatation of the vessels, we add something to their tone, and aid them to maintain that healthy balance which is opposed to the spread of the inflammatory process. So much we may well admit; but why, in the name of all that is reasonable, should such a proceeding be labeled with the special title of counter-irritation? It must be agreed by all that there is no propriety whatever in the term as thus applied. In short-and this is the burden of my paper, -the popular use of the term "counter-irritation" is thoroughly bad. And it is not a mere negative fault; it is a positive mischief. It is in vain that so-called practical men may protest that they simply act upon the facts observed in their experience, so long as they are weighed down with the carcase of a dead theory, which, although they do not know it, still hangs round their necks. It is in vain that they persuade themselves that they merely apply blisters or setons because they have seen them do good in similar cases; for the similarity is, perhaps, more frequently than not, more than half imaginary, and is assumed, unconsciously, in order to bring the case within the range of the supposed benefits of counter-irritation. And the readiness with which many practitioners conclude that any given case is appropriate for the application of this treatment is evidently due to a lingering love for something like a charm-for something mysterious, or even semi-fabulous, in its operation, as to which one need not inquire too closely, but which is definite and tangible in its outward shape-a weapon ready to the hand of the feeblest, as the smooth stones of the brook were ready to the sling of the stripling David.

\section{ON THE TREATMENT OF SCARLET FEVER.}

\section{By CHARLES T. THOMPSON, M.D., M.R.C.P.}

A FEW weeks ago Dr. Budd published an able paper on Scarlet Fever, and as he and I obtain similar results, though by different means, $I$ am desirous of submitting a few observations on the subject.

Instead of waiting till the third or fourth day to anoint the patient's body with oil, and to repeat this twice daily, in order to retain in situ the.infectious excreta from the skin, and after a longer or shorter interval washing this off in a warm bath, my practice is as follows:-

On the very first access of the fever, I put my patient into a warm bath, and repeat this as often as the strength of the patient will allow or the severity of the attack may require. The first effect of this treatment is to produce a soothing and refreshing feeling in the patient, to be followed soon by such an eruption on the surface, of so vivid a colour and in such amount, as would astonish those who have never witnessed it. Thus one of the greatest dangers of this fearful disease-the suppression of the eruption-is escaped.

After the first or second bath the appetite usually returns, so by getting down light and nutritious food the means are afforded of supporting the strength of the patient during one of the most trying periods of the disease. By this treatment the excreta from the skin are removed as rapidly as they are deposited, doing away immediately with the source of infection, leaving no room for the dissemination of the disease. The desquamation of the cuticle is greatly promoted, it being removed in small particles, and never in large pieces.

The drying of the body after the bath is effected by soft linen cloths, sufficiently large to envelop the whole person, and with as little friction as possible; in fact, the surface is what may be called "dabbed" dry, as the excitement from friction of the skin often produces great mischief.

The irritation of internal organs is also at once relieved by this continued determination to the surface. And as the condition of the latter becomes more healthy, the nasal, renal, and alvine secretions, with those of the throat,-in my opinion the most dangerous of all,--are speedily deprived of their noxious properties, and quickly recover a healthy character, thus again removing additional sources of infection.

The fever rapidly subsides, and convalescence usually proceeds more or less quickly, according to the mildness or severity of the attack. Another advantage of this treatment is, that a very serious case is soon reduced to a mild one, and the patient recovers in less than half the usual time.

This practice $I$ have pursued for more than fifteen years, during which period I have attended many cases of scarlet fever; but have never lost a single patient from this disease, nor can I call to mind at this moment any one case in which the infection has been carried from the patient to any other individual. I have had six or seven cases in a family at about one and the same time, the infection clearly traceable to schools, \&c.; yet have never known the disease spread to any others in the same household. I have also attended cases where isolation was impossible, or would not be attended to, the patients having free communication with other members of the family, but where the treatment above recommended has been scrupulously carried out, no second case has arisen. 
The consequence of all this is that, when the patient's health is sufficiently re-established, permission has been given to join the rest of the family; and I am satisfied that the patient might also be speedily restored to society with perfect safety. In no instance have I known any harm to arise from this permission. During the convalescence of the patient the bath, of course, may be used daily, or every other day, according to the feelings or wish of the patient; but its temperature should be gradually reduced, so as to invig rate and not exhaust, and also to enable the surface sucvesstully to resist the alternations of heat and cold to whic 1 tae patient may be exposed in moving about from place to place.

The terrible sequelæ of this formidable disease are, also, by the treatment above recommended, seldom if ever met wita. No nurse or washerwoman has, to my knowledge, suffered from the performance of her avocations. Of course the necessary medicines must be administered as occasion requires.

St. George's-road, Pimlico, Feb. 1869.

\section{CARBOLIC ACID IN THE TREATMENT OF CERTAIN DISEASES OF THE SKIN.}

\section{BY W. ST. JOHN COLEMAN, L.R.C.P., L.R.C.S.I.,} MEDTCAL OFFICER OF THE MILTOWN MATBAY DISPENSARY DISTRICT.

IT is in the treatment of the numerous class of skin diseases, more than any other, that the practitioner meets with the most provoking disappointments. It will be therefore not out of place to state briefly here the history of some cases treated with a new remedy, and the success which attended its application.

Eariy in October of last year I was consulted by Miss for a troublesome affection of the ears and forefinger of the left hand, which I made out to be eczema chronicum. I treated this with an ointment of white wax, hydrocyanic acid, and glycerine, and the exhibition of lime-water, and subsequently of iodide of potassium, internally. Having had, sume short time previously, some wounds under my care which I treated with a lotion of carbolic acid with much satisfaction, I bethought me that the same protection which this agent affords to nature in the suppurative proces in cases of wounds might equally be availed of in the heal ing pr scess attempted in the altered cutis. To an eightounce phial of glycerine and water $I$ added about twenty miaims* of pure carbolic acid, and applied it to the ears and finger sight and morning. The application exceeded $m y$ expectitions, and the eruption disappeared in a week, leaving a perfectly natural surface beneath. This lady had also her right leg affected with eczema xubrum, which had become c.rronic some three months previous to my treating her. 'lo this also the lotion was applied, and with perfect success.

Mrs D- had been treated by several physicians, myse'f mong the number, for the most troublesome and obstinate uruption of eczema faciei I have seen. From the success which attended the application of carbolic acid in Miss - 's case, I determined to try it in this. I did so, and with this result: that, whilst using the lotion, the face is perfectly smooth, and free from any trace of eruption; but, on its discontinuance, it invariably returns, though in a mitigated degree.

I do not know how many attempts I made to cure $D$. Cface was completely masked, several parts of his body being also affected. I only know that I was unsuccessful, and that othors were equally so. With the history of the cases related above before me, I could not do otherwise than give the carbolic acid a trial. Every bit of the scaly mask is now cleared off, and the skin, although presenting the characteristic redness, does so daily less in intensity, and is just recovering its natural softness.

I will add, as of much importance to the veterinary profession, that I have used a stronger lotion with much success in the treatment of "scab" in sheep.

Miltown Malbay, Co. Clare, Jan. 1869

\section{CASE OF TETANUS CURED BY BROMIDE OF POTASSIUM.}

\author{
BY R. H. BAKEWELL, M.D., M.R.C.S. ENa.
}

ON the 2nd January, 1869, I was called in to see a negress, aged about forty, living in a country village in Trinidad. I found her suffering from great pain, swelling, and tenderness of the left leg, on which there were two or three small but sloughy-looking ulcers. She was in a state of high fever. There was a very strong smell of garlic in the room, and I found that a good woman of the place had been rubbing the leg, including the sores, with a compound of garlic and oil.

I found, on inquiry, that the patient was a washerwoman, pursuing her avocation in the river, and that she had "caught cold" in the leg, which had inflamed and ulcerated. The reason why I was called was that on the previous day she had been attacked with stiffness in the jaws and inability to open them more than half an inch, and that on the morning of my visit she had had a violent spasm of the masseters, during which the jaws were completely clenched, with great pain. She complained, on inquiry, of pain in the back.

I ordered the immediate application of warm poultices and emollient fomentations to the leg; that beef-tea should be given every three hours, and half a drachm of bromide of potassium immediately, to be followed by a similar dose every four hours.

On my visit in the evening I found her in every respect better: the trismus had entirely disappeared, and she could open her mouth to its fullest extent; the pain in the back had gone, and the leg was less inflamed. As her head was somewhat giddy, and she had taken a drachm of the bromide, I ordered it to be discontinued; the other parts of the treatment as before.

She continued daily to improve; there was never any return of the lock-jaw; and she is now (Jan. 23rd) quite well.

Remarks.-This case is not of much importance by itself, but it may suggest to other practitioners the use of the bromide in tetanus, if it has not already been so used. I find nothing about its employment in this disease in the biennial report of the New Sydenham Society, nor have I noticed it in any of the medical journals.

Port of Spain, Trinidad, W.I.

\section{A ithinror}

OF THE PRACTICE OF

\section{MEDICINE AND SURGERY} IN THE

\section{HOSPITALS OF LONDON.}

Nulla autem est alia pro certo noscendi via, nisi quamplurimas et morborum et dissectionum historias, tum aliorum, tum proprias collectas habere, et et dissectionum historias, tum alorum, tum proprias collectas habere, et
inter se comparare.-Morgagn De Sed. et Caus. Morb., lib. iv. Procemium.

\section{KING'S COLLEGE HOSPITAL.}

CASE OF ASCITES DEPENDENT ON CIRRHOSIS OF THE LIVER, TREATED BY COPAIBA.

(Under the care of Dr. DUFFIN.)

A shorr time since, Dr. Garrod called our attention, whilst going round with him, to several of his dropsical patients who were taking copaiba with the effect of largely increasing the quantity of urine passed. In the following case Dr. Duffin employed the same remedy, with results which are very gratifying.

J. W-, aged fifty-one. During his younger years he had been a marine. He had resided both in the East and West Indies and on the shores of the Black Sea, and had suffered from dysentery and jungle fever. He admitted 